\title{
Evaluation of neuroprotective effect of flupirtine in brain of albino rats
}

\author{
Elango P*, Darling Chellathai, Saravana Babu
}

Department of Pharmacology, Sri Ramachandra Medical College, Sri Ramachandra University, Porur, Chennai - 600116, India

Received: 4 November 2015

Revised: 10 January 2016

Accepted: 11 January 2016

\section{*Correspondence to:}

Dr. Elango P,

Email: drpelango@yahoo.com

Copyright: (C) the author(s), publisher and licensee Medip Academy. This is an open-access article distributed under the terms of the Creative Commons Attribution NonCommercial License, which permits unrestricted non-commercial use, distribution, and reproduction in any medium, provided the original work is properly cited.

\begin{abstract}
Background: Flupirtine (FP) is found to antagonize both glutamate and $\mathrm{N}$ methyl, D aspartate (NMDA) and the current study was undertaken to elucidate a possible neuroprotective role of flupirtine against NMDA induced neurotoxicity in experimental rat model.

Methods: Excitotoxicty was produced in rat and it is counteracted by flupirtine. The animals were grouped as Group 1 (vehicle treated), Group 2 (received NMDA+vehicle), Group 3 (received FP+NMDA only), and Group 4 (received FP+vehicle) and were observed of animal behavior and oxidative stress biomarkers and also mRNA expression using reverse transcriptase-polymerase chain reaction (PCR PCR) was performed to determine the level of mRNA expression of acetyl cholinesterase (AChE) and muscarinic cholinergic receptor (MChR) in brain samples (hippocampus) of experimental animals.

Results: Depression effect induced by NMDA was reversed by flupirtine. Decrease in oxidative stress bio-markers associated with increase in the antioxidant enzyme activities in group 3 and 4 compared to group 1 and 2 . Gene expression were up-regulated in group 2 compared to 1, 3 and 4. Flupritine treatment reversed these alterations.

Conclusions: This study represents the neuroprotective characteristics of flupiritne against the excitotoxicity induced by NMDA in an in vivo rat models.
\end{abstract}

Keywords: Flupirtine, NMDA, Malondialdehyde, Glutathione, mRNA, AChE, MChR

\section{INTRODUCTION}

The major excitatory neurotransmitter in brain is glutamate. It acts on different classes of receptors, Gprotein-coupled metabotropic receptors and ionotropic glutaminergic receptors. The ionotropic receptors are further classified into N-methyl-D-aspartate (NMDA), kainate, and $\alpha$-amino-3-hydroxyl-5-methyl-4-isoxazolepropionate (AMPA) receptors. ${ }^{1}$ Glutamate binds to NMDA receptors, which results in $\mathrm{Ca}^{2+}$ entry from extracellular space into the cell. This leads to activation of $\mathrm{Ca}^{2+}$ - dependent enzymes like calpain, ${ }^{2}$ calcineurin, ${ }^{3}$ inducible nitric oxide synthase (iNOS) expression ${ }^{4}$ and cytosolic phospholipase $\mathrm{A}_{2}\left(\mathrm{cPLA}_{2}\right){ }^{5,6}$ In frontal cortex and hippocampal $\mathrm{CA}_{1}$ region NMDA receptors (NMDAR) are present predominantly. ${ }^{7}$ Activation of NMDAR also induces signalling cascades involved in behaviour and memory, synaptic excitability and plasticity, and neuronal degeneration. ${ }^{8}$ Excessive activation of glutamate receptors can result in the death of neurons through and excitotoxicity. Excitotoxicity has been implicated in several neurodegenerative diseases, like Alzheimer disease, ${ }^{9-11}$ Huntington disease, ${ }^{12}$ schizophrenia, ${ }^{13}$ and bipolar disorder. ${ }^{14-16}$ In in vivo animal models NMDA antagonists can reduce sustained seizures $^{17}$ and neuronal injury resulting from experimental hypoxia-ischemia. ${ }^{8-21}$ Development of additional potential neuroprotective compounds like flupritine would be help full in NMDA induced excitotoxicty and neuro degenerative disorders.

Flupirtine is a centrally acting non-opioid analgesic; it has been in clinical practice since 1984. In pain states have been reviewed extensively. ${ }^{22}$ Flupirtine exhibits potent cyto and neuro protective potential effects, in a clinically relevant dosage range. In our present study, the effect of flupiritne on chronic administration of NMDA to rats, as a model of excitotoxicity in brain. To the extent that this model represents clinical effect of flupiritine 
which might be used in NMDA induced behavioural and neurodegenerative disorders.

\section{METHODS}

Flupirtine, NMDA, normal saline, experimental animals and the facility for harbouring the animals and the conduct of the experiments. Sprague dawley rats (170$200 \mathrm{~g}$ ) were used in Center For Toxicology (CEFT), Sri Ramachandra university, Chennai, India and they were housed individually at $22 \pm 1{ }^{\circ} \mathrm{C}$ in cages with a 12 hours light dark cycle. All rats were allowed free access to the diet and water for 1 week for adaptation to the new environment. Rats were fed with standard laboratory pellets. The experimental protocol was approved by the Institutional Ethics Committee (IAEC) and conducted according to the Indian National Science Academy guidelines for the use and care of experimental animals. The animals were randomly assigned to 4 groups $(n=6$ each) as group 1 (vehicle treated), group 2 (received NMDA + vehicle), group 3 (received FP + NMDA only), and group 4 (received FP + vehicle). Excitotoxicity was produced in rat by intra peritoneal administration of NMDA ( $25 \mathrm{mg} / \mathrm{kg}$ body weight for 21 days) and it is counteracted by intra peritoneal administration of flupirtine ( $5 \mathrm{mg} /$ body weight for 21 days).

\section{Behavioural analysis}

\section{Anxiety and depression - elevated plus maze:}

Elevated plus maze is representative of those tests that are based upon the study of spontaneous behaviour pattern. Behavioural alteration was tested in control and treatment groups using elevated plus maze ${ }^{25}$ with slight modification. Parameters such as time spent in open arm and closed arm, number of entries to open arm and closed arm and number of head dips were recorded and analysed.

Anxiety, depression and exploratory behavior - open field exploratory test:

The test provides a unique opportunity to systematically assess novel environment exploration, general locomotors activity, and provide an initial screen for anxiety-related behaviour in rodents. Animals were allowed to freely explore the chamber for the duration of the test session. Each square crossed by the animal was scored. In addition to horizontal units of activity, rearing behaviour, defecation, and grooming activity were scored and analysed.

\section{Sacrifice of the animals and subsequent analysis}

At the end of the experiment, the rats were fasted overnight, subjected to anaesthesia with diethyl ether and sacrificed. The whole brain of each rat was rapidly dissected, washed with isotonic saline and dried on filter paper. Each brain was divided sagittally into two portions. The first portion was weighed and homogenized in ice-cold medium containing $50 \mathrm{mM}$ Tris/ $\mathrm{HCl}$ and 300 $\mathrm{mM}$ sucrose at $\mathrm{pH} 7.4$ to give a $10 \%(\mathrm{w} / \mathrm{v})$ homogenate. ${ }^{26}$ This homogenate was centrifuged at $1400 \times \mathrm{g}$ for $10 \mathrm{~min}$ at $4{ }^{\circ} \mathrm{C}$. The supernatant was stored at $-80^{\circ} \mathrm{C}$ and used for biochemical analyses that included oxidative stress biomarkers (SOD and MDA), antioxidant status (GSH), and gene expression in rat brain, the second portion of the brain was fixed in $10 \%$ formalin for histological investigation.

\section{Biochemical analysis}

Determination of superoxide dismutase activity:

Superoxide dismutase (SOD) activity in $10 \%$ brain homogenate was assayed spectrophotometerically. ${ }^{27}$ One unit of SOD activity was calculated as the amount of protein required to give $50 \%$ inhibition of phenazonium methosulphate-nitro blue tetrazolium (PMS-NBT) auto oxidation. The activity of SOD was expressed in unit $/ \mathrm{min} / \mathrm{mg}$ of protein.

\section{Determination of lipid peroxidation (TBARS):}

Lipid peroxidation was assessed as thiobarbituric acidreactive substance concentrations in $10 \%$ tissue homogenate. Values are expressed in $\mathrm{mg} / \mathrm{dl}$ homogenate. ${ }^{28}$

\section{Estimation of reduced glutathione:}

Reduced glutathione (GSH) was estimated based on the reaction of GSH with dithiobistrinitro benzoic acid (DTNB). The absorbance was read at $412 \mathrm{~nm}$. The values were expressed in $\mu \mathrm{g}$ of glutathione/ml homogenate. ${ }^{29}$

\section{mRNA expression of AChE and MChR}

Reverse transcriptase (RT) - polymerase chain reaction (PCR) was performed to determine the level of mRNA expression of AChE and MChR in brain sample of experimental animals. Briefly, $50 \mathrm{mg}$ of tissue was homogenized with $500 \mu \mathrm{l}$ TRIzol and the tubes were incubated for $10 \mathrm{~min}$ and centrifuged at $1000 \mathrm{rpm}$ for 5 min. $200 \mu \mathrm{l}$ of chloroform was added to the supernatant, allowed to incubate for $5 \mathrm{~min}$ at room temperature and centrifuged at $12000 \mathrm{rcf}$ for $20 \mathrm{~min}$. Then $500 \mu \mathrm{l}$ of isopropyl alcohol was added to the supernatant to precipitate the total RNA and centrifuged at $12000 \mathrm{rcf}$ for $15 \mathrm{~min}$ following the incubation period of $10 \mathrm{~min}$. The supernatant was decanted carefully; the pellet was washed three times with $75 \%$ ethanol, centrifuged at $12000 \mathrm{rcf}$ for $15 \mathrm{~min}$ and the pellet was allowed to air dry. The pellet was resuspended in $20 \mu \mathrm{l}$ of RNase free water and stored in $-80^{\circ} \mathrm{C}$ until use. The isolated RNA was allowed to undergo reverse transcription and polymerization reaction to get cDNA using PCR master cycler gradient. PCR products were electrophoresed at $80 \mathrm{~V}$ for 30 min using $1.0 \%$ agarose gel with ethidium 
bromide stain. 200 nanograms of RNA was used for reverse transcription polymerase chain reaction (RTPCR) according to the manufacturer's instructions (Genet Bio, Korea). The following sequence was performed for each PCR reaction: $42^{\circ} \mathrm{C}$ for $30 \mathrm{~s}, 94^{\circ} \mathrm{C}$ for $5 \mathrm{~min}(1$ cycle); $94^{\circ} \mathrm{C}$ for $1 \mathrm{~min}, \beta$-actin $\left(55.4^{\circ} \mathrm{C}\right), \operatorname{AChE}\left(60.6^{\circ} \mathrm{C}\right)$ and $\mathrm{MChR}\left(59.4^{\circ} \mathrm{C}\right.$ ) for $1 \mathrm{~min}$, and $72^{\circ} \mathrm{C}$ for $1 \mathrm{~min}$ (with 35 cycles); and a final extension phase at $74^{\circ} \mathrm{C}$ for 10 min. ${ }^{30}$

\section{Histopathology analysis}

All the surviving rats at the end of the experimental period were euthanized using overdose of anaesthetic ether. Brains were collected from rats of all experimental groups and fixed in $10 \%$ neutral buffered formalin. Representative tissue section of brain at the level of hippocampus region were trimmed and dehydrated in series of graded alcohol and embedded in paraffin wax. Tissue sections of 3-4 micron thickness were obtained, mounted on a clean glass slides and stained with haematoxylin and eosin (H\&E) for microscopic evaluation. $^{31}$

\section{Statistical analysis}

Data were expressed as mean $(\mathrm{X}) \pm$ standard error of mean (SEM). The results were analysed for statistical significance by one-way analysis of variance (ANOVA) test using prism 5.0.

\section{RESULTS}

\section{Behavioural Analysis}

In elevated plus maze method reduced entries into open arm, time spent on the open arms, was seen in the group 2 compared to the group 1 while entries into close arm, time spent on the close arms, head dip and number of fecal pellets were increased $(\mathrm{p}<0.05)$ (Table 2). In comparison to the group 2, in the group 3 and 4, there were significant reduced entries into close arm, time spent on the close arm and entries into open arm, time spent on the open arms increased $(\mathrm{p}<0.05)$. But head dip and number of fecal pellets were no reduced group 3, 4 compare to group 2 there was no significant.

In open field method a reduced in no. of crosses on squares was seen in the group 2 (NMDA induced) compared to the group 1 while immobility period $(\mathrm{sec})$, rearing, grooming, fecal pellets were increased, $(\mathrm{p}<0.05)$ (Table 1). In comparison to the group 2, in the group 3 and 4 , there were significant reduced in immobility period (sec), rearing, grooming, fecal pellets and No. of squares crosses increased $(\mathrm{p}<0.05)$.

\section{Bio chemical analysis}

Among the parameters evaluated in the brain tissue extracted from rats, a decrease in SOD, glutathione level was seen in the group 2 compared to the group 1 while MDA levels were increased ( $\mathrm{p}<0.05$ ) (Figure 1, 2, 3). In comparison to the group 2, in the group 3, 4 there were significant decreases in MDA while SOD and glutathione had increased $(\mathrm{p}<0.05)$.

\section{Gene (mRNA) expression of AChE and MChR}

AChE and MChR gene (mRNA) expression were found to be up-regulated in group 2 when compared to group 1, 3 and 4. Flupritine treatment reversed these alterations (Figure 4 \& Table 3).

\section{Histopathology analysis}

Histological profile in group 1 revealed normal architecture of neurons in the $\mathrm{CA}$ regions of hippocampus. In group 2 no treatment related changes were observed in the CA regions of hippocampus. Group 3 and group 4 remains to be similar and no treatment related changes have been noticed in the tissue sections of the CA region of hippocampus (Figure 5).

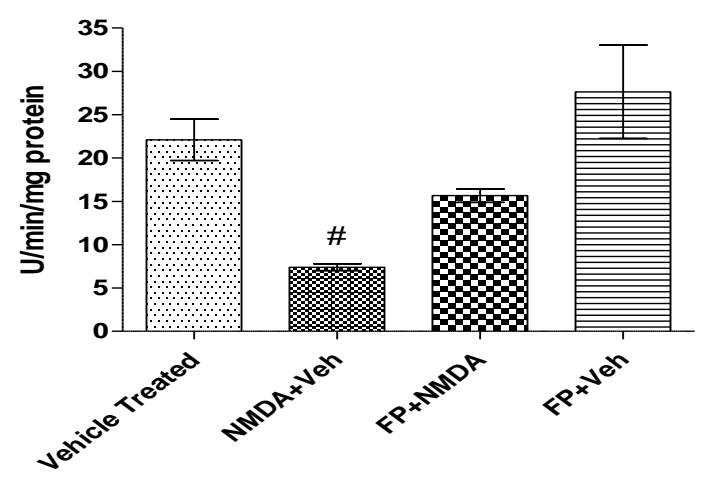

Figure 1: Effect of flupritine on SOD activity in NMDA induced rats.

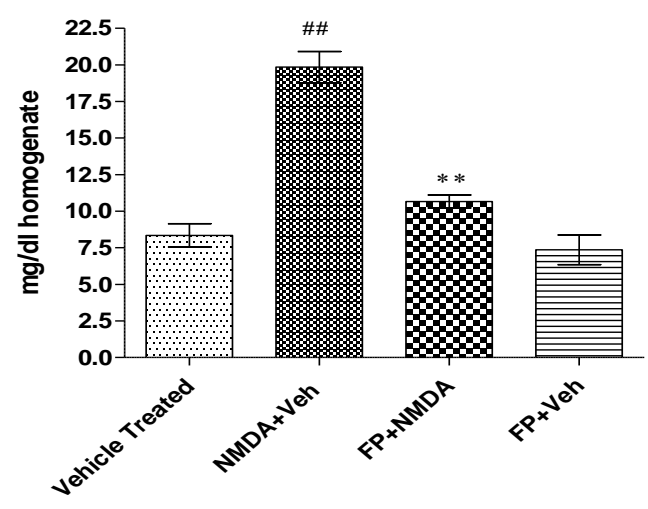

Figure 2: Effect of flupritine on lipid peroxicdation in NMDA induced rats. 


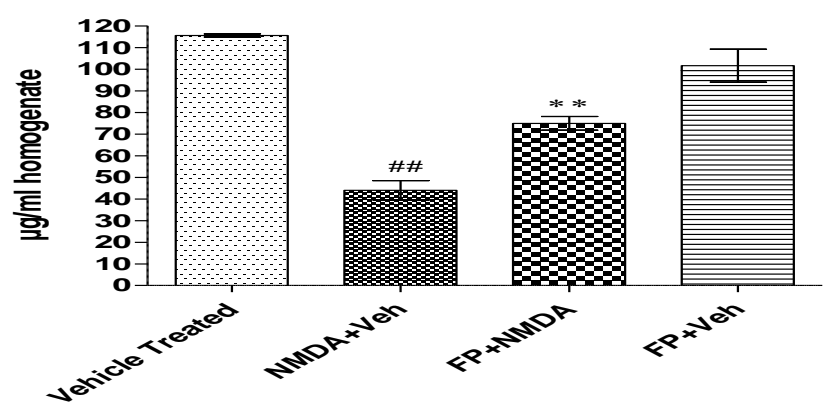

Figure 3: Effect of flupritine on glutathione content in NMDA induced rats.

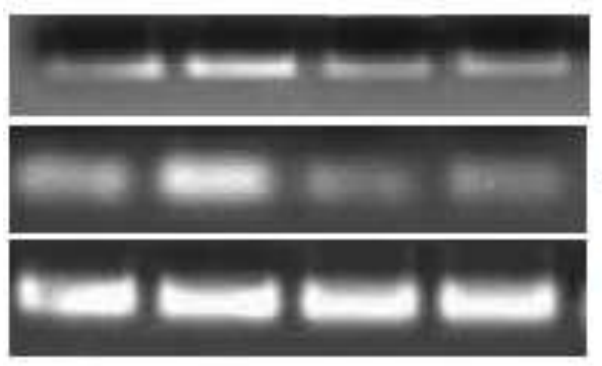

\section{MChR}

$\mathrm{AChE}$

$\beta$-actin

Figure 4: Lane 1: Normal control; Lane 2: NMDA + Vehicle; Lane 3: NMDA + FP and Lane 4: Vehicle + FP.
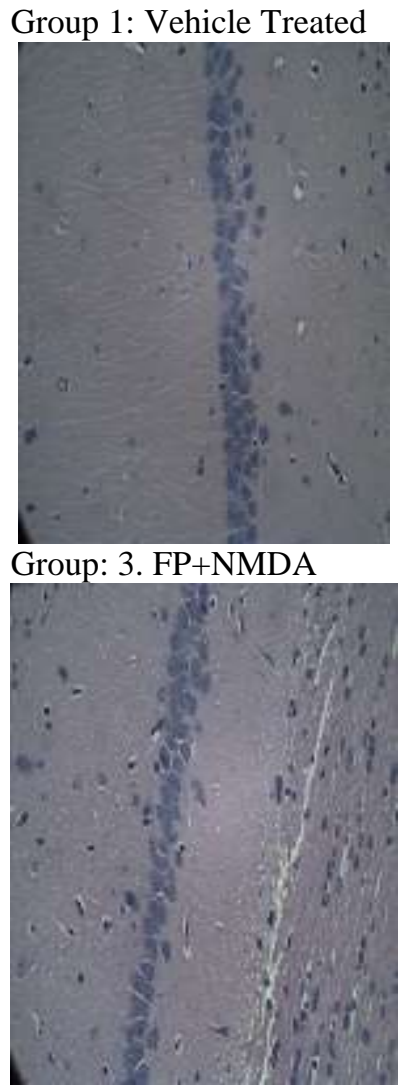

Group: 2. NMDA+ Vehicle

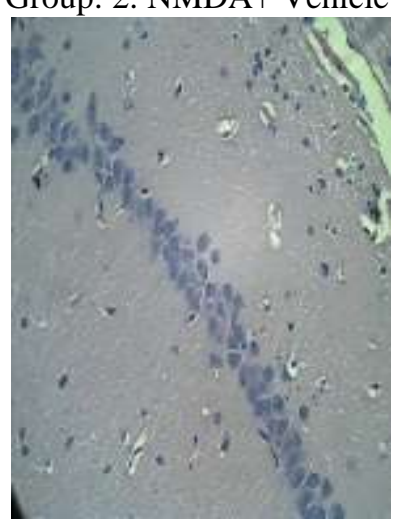

Group: 4. FP+vehicle

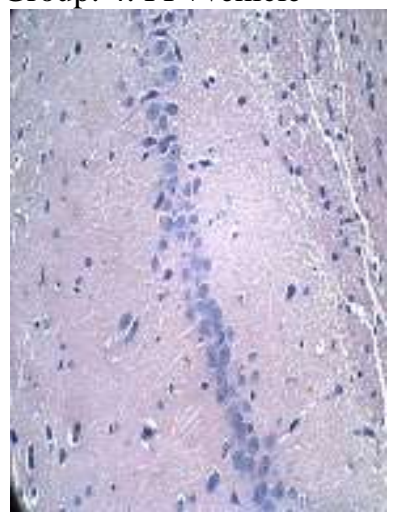

Figure 5: Histo pathological Changes.

Table 1: Anxiety, depression and exploratory behaviour - open field exploratory test.

\begin{tabular}{|llllll|}
\hline Treatment & $\begin{array}{l}\text { No.of squares } \\
\text { crosses }\end{array}$ & $\begin{array}{l}\text { Immobility period } \\
\text { (Sec) }\end{array}$ & Rearing & Grooming & Fecal pellet \\
\hline Vehicle treated & $79.67 \pm 10.26$ & $14.33 \pm 5.03$ & $6.67 \pm 1.23$ & $2.83 \pm 0.48$ & $1.00 \pm 0.26$ \\
\hline NMDA+Veh & $50.00 \pm 10.43$ & $135.17 \pm 25.27$ & $16.67 \pm 3.42$ & $7.50 \pm 2.55$ & $2.00 \pm 0.26$ \\
\hline FP+NMDA & $73.60 \pm 14.33$ & $78.20 \pm 17.36$ & $12.00 \pm 2.72$ & $4.00 \pm 0.87$ & $0.80 \pm 0.34$ \\
\hline FP+Vehicle & $56.67 \pm 5.71$ & $59.50 \pm 17.83$ & $6.33 \pm 0.56$ & $5.17 \pm 0.48$ & $1.17 \pm 0.17$ \\
\hline
\end{tabular}

Table 2: Anxiety and depression - elevated plus maze.

\begin{tabular}{|lllllll|}
\hline Treatment & No.of Entries & \multicolumn{5}{c}{ Time Spent } \\
& Open arm & Closed arm & Open arm & Closed arm $\begin{array}{l}\text { No of head } \\
\text { dips }\end{array}$ & Fecal pellets \\
\hline $\begin{array}{l}\text { Vehicle } \\
\text { treated }\end{array}$ & $11.67 \pm 1.31$ & $7.50 \pm 0.76$ & $344.50 \pm 8.40$ & $132.67 \pm 8.99$ & $3.67 \pm 0.49$ & $1.50 \pm 0.34$ \\
\hline NMDA+Veh & $6.67 \pm 0.42$ & $21.50 \pm 1.12$ & $101.83 \pm 6.72$ & $379.83 \pm 4.31$ & $3.33 \pm 0.56$ & $3.17 \pm 0.48$ \\
\hline FP+NMDA & $7.00 \pm 0.32$ & $24.20 \pm 1.86$ & $190.80 \pm 23.78$ & $256.40 \pm 18.16$ & $2.60 \pm 0.37$ & $3.00 \pm 0.29$ \\
\hline FP+Vehicle & $9.33 \pm 0.80$ & $15.67 \pm 1.41$ & $219.50 \pm 31.82$ & $236.83 \pm 34.62$ & $3.33 \pm 0.80$ & $3.00 \pm 0.58$ \\
\hline
\end{tabular}

Table 3: Gene expression.

\begin{tabular}{|llll|}
\hline S. No & $\begin{array}{l}\text { Gene } \\
\text { Marker }\end{array}$ & Forward primer & Reverse primer \\
\hline $\mathbf{1}$ & $\beta$-actin & 5'-GACATGGAGAAAATCTGGCA-3' & 5'-AATGTCACGCACGATTTCCC-3' \\
\hline $\mathbf{2}$ & AChE & 5'GCAGAACTTCACTGACCAAAA3' & 5'TCAAAGGAGGGGGACTCATA- 3' \\
\hline $\mathbf{3}$ & MChR & 5'-CTGTCACGGTCATGTGTACACTGT-3' & 5'CCGGGCTCGGTTTCTGT-3' \\
\hline
\end{tabular}




\section{DISCUSSION}

NMDA is an excitatory neuro transmitter. In addition to their physiological functions, mounting evidence has suggested their involvement in excitotoxicity. Cell death triggered by seizure or ischemic stroke is attributed to NMDAR over activation. ${ }^{32-33}$ Abnormal NMDAR activity is also associated with neurodegenerative disorders, such as Alzheimer's, Huntington's, and Parkinson's disease. ${ }^{34}$ In vitro and in vivo studies have suggested that flupirtine antagonizes the neurotoxicity caused by the prion agent PrPSc and lead acetate $\left[\mathrm{Pb}\left(\mathrm{C}_{2} \mathrm{H}_{3} \mathrm{O}_{2}\right)_{2} \bullet 3 \mathrm{H}_{2} \mathrm{O}\right]$ mediated by NMDA receptors. ${ }^{35}$ Flupirtine significantly inhibits the neurotoxic effect caused by amyloid $\beta$-protein segments in Alzheimer's disease ${ }^{36}$ and other neurological disorders, such as amyotrophic lateral sclerosis. ${ }^{37}$ Studies using animal models have also revealed that flupirtine counteracts the effects of retinal and cerebral ischemia. ${ }^{38-}$

${ }^{39}$ In another study, the long-term flupirtine treatment of chronic pain prevents retinal ganglion cells from degeneration in a non-inflammatory animal model of optic nerve transmission. This result indicated that this drug is a potential candidate and should be further evaluated in terms of its neuroprotective potential. ${ }^{40}$ Different molecular mechanisms may also account for flupirtine-mediated neuroprotection. Our previous study indicated flupiritine has neuroprotective effect of on U373 MG cells, which limits its use in the pain management of brain tumors. ${ }^{41}$ This property warrants further studies using animal models and large - scale clinical trials.

This study represents the neuroprotective characteristics of flupiritne against to NMDA induced excitotoxicity in an in vivo system. The findings of this study is discussed here.

\section{Behavioral analysis}

In elevated plus maze test, the reduction in number of entries and the time spent in open arm and increased number of entries and the time spent in closed arm in NMDA treated animals are reversed in FP treated animals. In open field exploratory test the effects are like reduced no of square cross and increased immobility time, increased rearing and grooming activity with increased no of fecal pellets in NMDA treated animals. These effects are reversed in FP treated animals. These behavioural changes are significant to the antidepressant and antianxiety effect of FP.

\section{Biochemical analysis}

The excitotoxic neurotransmitter, NMDA signals in behaviour, memory, synaptic excitability and plasticity. ${ }^{8}$ Excessive activation of the receptor results in neuronal degeneration. NMDA treated animals showed decrease in SOD, GSH levels and elevated levels in MDA. These changes are the markers in excititoxicity and confirm the effects of NMDA. These effects are counteracted by FP in the animals treated with FP as per the changes observed in above biochemical parameters. Thus, NMDAR activation is essential for neuronal survival and physiological functions; excessive activation contributes to pathological changes including cell death. ${ }^{42}$

\section{mRNA expression of AChE and MChR}

The up regulation of AchE and MchR in NMDA treated animals is reversed in FP treated animals showing significant interaction between NMDA and FP.

\section{Histopathology analysis}

In histopathological view of hippocampus regions of brain showed no treatment related changes because it is supposed that the doses may not be sufficient to elicit histopathological changes in neurons. This gives way for further exploration to study the effect of the drugs in higher doses.

\section{CONCLUSION}

Flupirtine is a centrally acting non-opioid analgesic and also flupirtine exhibits potent cyto and neuro protective potential effects which is exhibited as the effect of FP on chronic administration of NMDA to rats, as a model of excitotoxicity in brain. This drug is a potential candidate and should be further evaluated in terms of its neuroprotective potential. These evidence based studies proved neurodegenerative effect of NMDA and neuroprotective effect of FP in addition to its antidepressant and antianxiety effects.

\section{ACKNOWLEDGMENTS}

This study was supported by an intramural grant from Sri Ramachandra University, Chennai.

Funding: No funding sources

Conflict of interest: None declared

Ethical approval: The study was approved by the Institutional Ethics Committee

\section{REFERENCES}

1. Nakanishi S. Molecular diversity of glutamate receptors and implications for brain function. Science. 1992;258(5082):597-603.

2. Siman R, Noszek JC. Excitatory amino acids activate calpain and induce structural protein breakdown in vivo. Neuron. 1988;1(4):279-87.

3. Xifro X, Garcia-Martinez JM, Del Toro D, Alberch J, Perez-Navarro E. Calcineurin is involved in the early activation of NMDA-mediated cell death in mutant huntingtin knock-in striatal cells. J Neurochem. 2008;105(5):1596-612.

4. Chang YC, Kim HW, Rapoport SI, Rao JS. Chronic NMDA administration increases neuroinflammatory markers in rat frontal cortex: cross-talk between 
excitotoxicity and neuroinflammation. Neurochem Res. 2008,33(11):2318-23.

5. Weichel O, Hilgert M, Chatterjee SS, Lehr M, Klein J. Bilobalide, a constituent of Ginkgo biloba, inhibits NMDA-induced phospholipase $\mathrm{A}_{2}$ activation and phospholipid breakdown in rat hippocampus. Naunyn Schmiedebergs Arch Pharmacol. 1999;360(6):609-15.

6. Rao JS, Ertley RN, Rapoport SI, Bazinet RP, Lee HJ. Chronic NMDA administration to rats upregulates frontal cortex cytosolic phospholipase $\mathrm{A}_{2}$ and its transcription factor, activator protein-2. J Neurochem. 2007;102(6):1918-27.

7. Monaghan DT, Cotman CW. Distribution of Nmethyl-D-aspar-tate-sensitive $\quad$ L- $[3 \mathrm{H}]$ glutamatebinding sites in rat brain. $\mathrm{J}$ Neurosci 1985;5(11):2909-19.

8. Tilleux S, Hermans E. Neuroinflammation and regulation of glial glutamate uptake in neurological disorders. J Neurosci Res. 2007;85(10):2059-70.

9. Fang M, Li J, Tiu SC, Zhang L, Wang M, Yew DT: $\mathrm{N}$-methyl-D- aspartate receptor and apoptosis in Alzheimer's disease and multiinfarct dementia. J Neurosci Res. 2005;81(2):269-74.

10. Snyder EM, Nong Y, Almeida CG, Paul S, Moran T, Choi EY, Nairn AC, Salter MW, Lombroso PJ, Gouras GK, et al. Regulation of NMDA receptor trafficking by amyloid-beta. Nat Neurosci. 2005;8(8):1051-8.

11. Hallett PJ, Dunah AW, Ravenscroft P, Zhou S, Bezard E, Crossman AR, Brotchie JM, Standaert DG. Alterations of striatal NMDA receptor subunits associated with the development of dyskinesia in the MPTP-lesioned primate model of Parkinson's disease. Neuropharmacology. 2005;48(4):503-16.

12. Young AB, Greenamyre JT, Hollingsworth Z, Albin R, D'Amato C,Shoulson I, Penney JB. NMDA receptor losses in putamen from patients with Huntington's disease. Science. 1988;241(4868):9813.

13. Mueller HT, Meador-Woodruff JH. NR3A NMDA receptor subunit mRNA expression in schizophrenia, depression and bipolar disorder. Schizophr Res. 2004,71(2-3):361-70.

14. Basselin M, Chang L, Bell JM, Rapoport SI. Chronic lithium chloride administration attenuates brain NMDA receptor-initiated signaling via arachidonic acid in unanesthetized rats. Neuropsychopharmacology. 2006,31(8):1659-74.

15. Basselin M, Villacreses NE, Chen M, Bell JM, Rapoport SI. Chronic carbamazepine administration reduces N-methyl-D-aspartate receptor-initiated signaling via arachidonic acid in rat brain. Biol Psychiatry. 2007,62(8):934-43.

16. Clinton SM, Meador-Woodruff JH: Abnormalities of the NMDA receptor and associated intracellular molecules in the thalamus in schizophrenia and bipolar disorder. Neuropsychopharmacology. 2004;29(7):1353-62.
17. Labuyere J, Fuller TA, Olney JW, Price MT, Zorumski C, Clifford D. Phencyclidine and ketamine protect against kainic acid-induced seizure related damage. Soc Neurosci Abstr. 1986;12:344.

18. Boast CA, Gerhardt SC, Pastor G., Lehmann J, Etienne PE, Liebman, JM. The N-methyl-Daspartate antagonist CGS19755 and CPP reduce ischemic brain damage in gerbils. Brain Res. 1988;442:345-8.

19. Gill R, Foster C, Woodruff GN. Systemic administration of MK-801 protects against ischemiainduced hippocampal neurodegeneration in the gerbil, J. Neurosci. 1987;7:3343-9.

20. McDonald JW, Silverstein FS, Johnston MV. MK801 protects the neonatal brain from hypoxicischemic damage. Eur J Pharmacol. 1987;140:35961.

21. Simon RP, Swan JH, Griffiths T, Meldrum BS. Blockade of $\mathrm{N}$-methyl-D-aspartate receptors may protect against ischemic damage in the brain, Science. 1984;226:850-2.

22. Harish S, Bhuvana K, Bengalorkar GM, Kumar TN. Flupirtine: clinical pharmacology. J Anaesthesiol Clin Pharmacol. 2012;28(2):172-7.

23. Basselin M, Chang L, Bell JM, Rapoport SI. Chronic lithium chloride administration to unanesthetized rats attenuates brain dopamine $\mathrm{D}_{2}$ like receptor-initiated signaling via arachidonic acid. Neuropsychopharmacology. 2005;30(6):1064-75.

24. Ormandy GC, Song L, Jope RS. Analysis of the convulsant-potentiating effects of lithium in rats. Exp Neurol. 1991;111(3):356-61.

25. Varty GB, Morgan CA, Cohen-Williams ME, Coffin VL, Carey GJ. The gerbil elevated plus-maze i: behavioral characterization and pharmacological validation Neuropsychopharmacology. 2002;27:57370.

26. Tsakiris S; Schulpis K; Marinou K, Behrakis P. Protective effect of L-cysteine and glutathione on the modulated sucking rat brain $\mathrm{Na}^{+} \mathrm{K}^{+}$, ATPase and $\mathrm{Mg}^{2+}$-ATPase activities induced by the in vitro galactosaemia. Pharmacol Res. 2004;49:475-9.

27. Kakkar P, Das B, Viswanathan PNA. Modified spectrophotometric assay of superoxide dismutase. Ind. J Biochem Biophys. 1984;21:130-2.

28. Ohkawa H, Ohishi N, Yagi K. Assay of lipid peroxides in animal tissues by thio babituric acid reaction. Anal Biochem. 1979;95:351.

29. Moren MS, Desplerra JW, Mannervick B. Levels of glutathione, glutathione reductase and glutathione $\mathrm{S}$ transferase activity in rat liver and lung. Biochimica Biophysica Acta. 1979;585:67.

30. Allgaier C, Scheibler P, Müller D, Feuerstein TJ, Illes P. NMDA receptor characterization and subunit expression in rat cultured mesencephalic neurons. $\mathrm{Br}$ J Pharmacol. 1999;126(1):121-30.

31. Nagaraja H, Kumar P. Neuroprotective effect of Centella asiatica extract (CAE) on experimentally induced parkinsonism in aged Sprague-Dawley rats. J Toxicol Sci. 2010;35(1):41-7. 
32. Obermeier K, Niebch G, Thiemer K Pharmacokinetics and biotransformation of the analgesic flupirtine in the rat and dog. Arzneimittelforschung. 1985;35:60-7.

33. Hlavica P, Niebch G. Pharmacokinetics and biotransformation of the analgesic flupirtine in humans. Arzneimittelforschung. 1985;35:67-4.

34. Li C, Ni J, Wang Z, Li M, Gasparic M, Terhaag B, Uberall MA. Analgesic efficacy and tolerability of flupirtine vs. tramadol in patients with subacute low back pain: a double-blind multicentre trial. Curr Med Res Opin. 2008;24:3523-30.

35. Perovic S, Schröder HC, Pergande G, Ushijima H, Müller WE. Effect of flupirtine on Bcl-2 and glutathione level in neuronal cells treated in vitro with the prion protein fragment (PrP106-126). Exp Neurol. 1997;147:518-24.

36. Perovic S, Böhm M, Meesters E, Meinhardt A, Pergande G, Müller WE. Pharmacological intervention in age-associated brain disorders by Flupirtine: Alzheimer's and prion diseases. Mech Ageing Dev. 1998;101:1-19.

37. Müller WE, Romero FJ, Perovic S, Pergande G, Pialoglou P. Protection of flupirtine on beta- amyloid-induced apoptosis in neuronal cells in vitro: prevention of amyloid-induced glutathione depletion. J Neurochem. 1997;68:2371-7.

38. Block F, Schwarz M, Sontag KH. Retinal ischemia induced by occlusion of both common carotid arteries in rats as demonstrated by electroretinography. Neurosci Lett. 1992;144:124-6.

39. Rupalla K, Cao W, Krieglstein J. Flupirtine protects neurons against excitotoxic or ischemic damage and inhibits the increase in cytosolic $\mathrm{Ca}^{2+}$ concentration. Eur J Pharmacol. 1995;294:469-73.

40. Sättler MB, Williams SK, Neusch C, Otto M, Pehlke JR, Bähr M, et al. Flupirtine as neuroprotective addon therapy in autoimmune optic neuritis. Am J Pathol. 2008;173:1496-1507.

41. Panchanathan E, Ramanathan G, Lakkakula BV. Effect of flupirtine on the growth and viability of U373 malignant glioma cells. Cancer Biol Med. 2013;10:142-7.

42. Harish S, Bhuvana K, Bengalorkar GM, Kumar T. Flupirtine: clinical pharmacology. J Anaesthesiol Clin Pharmacol. 2012;28:172-7.

Cite this article as: Elango $\mathrm{P}$, Chellathai $\mathrm{D}, \mathrm{Babu} \mathrm{S}$. Evaluation of neuroprotective effect of flupirtine in brain of albino rats. Int $\mathrm{J}$ Basic Clin Pharmacol 2016;5:135-41. 